\title{
Alcohol Elicits Functional and Structural Plasticity Selectively in Dopamine D1 Receptor-Expressing Neurons of the Dorsomedial Striatum
}

\author{
이 Jun Wang, ${ }^{1,2}$ Yifeng Cheng, ${ }^{1}$ Xuehua Wang, ${ }^{1}$ Emily Roltsch Hellard, ${ }^{1}$ Tengfei Ma, ${ }^{1}$ Hannah Gil, ${ }^{2}$ Sami Ben Hamida, ${ }^{2}$ \\ and Dorit Ron ${ }^{2}$ \\ ${ }^{1}$ Department of Neuroscience and Experimental Therapeutics, College of Medicine, Texas A\&M Health Science Center, Bryan, Texas 77807, and \\ ${ }^{2}$ Department of Neurology, University of California San Francisco, San Francisco, California 94143
}

Addiction is thought to be a maladaptive form of learning and memory caused by drug-evoked aberrant synaptic plasticity. We previously showed that alcohol facilitates synaptic plasticity in the dorsomedial striatum (DMS), a brain region that drives goal-directed behaviors. The majority of DMS cells are medium spiny neurons (MSNs) that express dopamine D1 receptors (D1Rs) or D2 receptors (D2Rs), which drive "Go" or "No-Go" behaviors, respectively. Here, we report that alcohol induces cell type-specific synaptic and structural plasticity in the DMS. Using mice that express a fluorescence marker to visualize D1R or D2R MSNs, we show that repeated cycles of systemic administration of alcohol or alcohol consumption induces a long-lasting increase in AMPAR activity specifically in DMS D1R but not in D2R MSNs. Importantly, we report that alcohol consumption increases the complexity of dendritic branching and the density of mature mushroom-shaped spines selectively in DMS D1R MSNs. Finally, we found that blockade of D1R but not D2R activity in the DMS attenuates alcohol consumption. Together, these data suggest that alcohol intake produces profound functional and structural plasticity events in a subpopulation of neurons in the DMS that control reinforcement-related learning.

Key words: addiction; alcohol; dendritic spines; dorsal striatum; ethanol; synaptic plasticity

Significance Statement

Alcohol addiction is considered maladaptive learning and memory processes. Here we unraveled a long-lasting cellular mechanism that may contribute to the memory of alcohol-seeking behaviors. Specifically, we found that alcohol consumption produces a long-lasting enhancement of channel activity and persistent alterations of neuronal morphology in a part of the brain (DMS) that controls alcohol-drinking behaviors. Furthermore, we show that these alterations occur only in a subpopulation of neurons that positively control reward and reinforcement of drugs of abuse. Finally, we report that blocking the activity of this neuronal population reduces alcohol intake. As such synaptic and structural changes are the cellular hallmarks of learning and memory, and these neuroadaptations may drive the development of pathological heavy alcohol consumption.

\section{Introduction}

Exposure to drugs of abuse alters glutamatergic neurotransmission, causing long-term synaptic and structural plasticity, which are thought to drive addiction-related behaviors (Russo et al., 2010). For example, exposure of rodents to cocaine increases

Received Jan. 1, 2015; revised July 8, 2015; accepted July 14, 2015.

Author contributions: J.W. and D.R. designed research; J.W., Y.C., X.W., E.R.H., T.M., H.G., and S.B.H. performed research; J.W., Y.C., H.G., S.B.H., and D.R. analyzed data; J.W. and D.R. wrote the paper.

This research was supported by the National Institute on Alcohol Abuse and Alcoholism (R01AA014366 and U01AA023489 to D.R., R01AA021505 to J.W., and P50 AA017072 to D.R. and J.W.), by funds provided by the State of California (D.R.), by the Alcoholic Beverage Medical Research Foundation (J.W.), and by the 2014 John P. McGovern Award from the Texas Research Society on Alcoholism (Y.C.). We thank Eric Zhao and Emily Zheng for technical support and Jacob Beckley for critical review of this manuscript.

The authors declare no competing financial interests.
GluN2B-containing NMDAR activity (Schilström et al., 2006; Huang et al., 2009), induces long-term synaptic plasticity (Ungless et al., 2001; Saal et al., 2003), and triggers persistent changes in dendritic and spine morphology (Russo et al., 2010) in NAc and VTA. Alcohol also increases GluN2B activity and modulates synaptic plasticity in the bed nucleus of the stria terminalis (Kash et al., 2009; Wills et al., 2012) and the VTA (Stuber et al., 2008). We previously found that chronic intermittent intake of 5-6

Correspondence should be addressed to either of the following: Jun Wang, 8447 State Highway 47, Suite 2106, Bryan, TX 77807, E-mail: jwang@medicine.tamhsc.edu; or Dorit Ron, 675 Nelson Rising Lane, Box 0663, San Francisco, CA 94143-0663, E-mail: dorit.ron@ucsf.edu.

S. Ben Hamida's present address: Douglas Mental Health Institute, McGill University, Montréal, Canada. DOI:10.1523/JNEUROSCI.0003-15.2015

Copyright $\odot 2015$ the authors $\quad 0270-6474 / 15 / 3511634-11 \$ 15.00 / 0$ 
$\mathrm{g} / \mathrm{kg} / \mathrm{d}$ of alcohol in rats, which models excessive alcohol drinking in humans (Carnicella et al., 2014), induces long-term facilitation (LTF) of GluN2B activity selectively in the dorsomedial striatum (DMS; Wang et al., 2010a), a brain region essential for drug and alcohol addiction (Koob and Volkow, 2010). We further showed that alcohol-mediated LTF in the DMS facilitates the induction of long-term potentiation (LTP) of AMPAR-mediated transmission (Wang et al., 2012). Finally, we demonstrated that GluN2B and AMPARs in the DMS contribute to mechanisms that underlie the development and maintenance of excessive alcohol consumption and relapse to alcohol seeking (Wang et al., 2010a, 2012).

The principal cells of the striatum are medium spiny neurons (MSNs), which express dopamine D1 receptors (D1Rs) or D2 receptors (D2Rs) (Gerfen and Surmeier, 2011; Calabresi et al., 2014). Similar to other addictive drugs, alcohol exposure increases extracellular dopamine levels in the striatum (Gonzales et al., 2004; Sulzer, 2011). Dopamine binding to G $\alpha$ s-coupled D1Rs or G $\alpha \mathrm{i}$-coupled D2Rs activates or inhibits, respectively, the cAMP/PKA pathway (Neve et al., 2004). Alcohol activates PKA signaling (Ron and Messing, 2013), which increases GluN2B phosphorylation and NMDAR activity (Yaka et al., 2003b; Thornton et al., 2004; Darcq et al., 2014b). Furthermore, alcohol enhances GluN2B activity in a mechanism that requires PKA (Yaka et al., 2003a; Wang et al., 2007). Finally, induction of dorsostriatal AMPAR-LTP requires PKA signaling (Calabresi et al., 2000; Hawes et al., 2013). Thus, we tested the hypothesis that alcohol consumption induces a D1R MSN-specific, long-lasting neuroadaptation in AMPAR activity. Long-term synaptic plasticity of AMPAR-mediated transmission may lead to and/or be associated with morphological changes in neurons (Kasai et al., 2010), and exposure to drugs of abuse induces structural plasticity, including alterations in dendritic complexity and spines (Russo et al., 2010). Thus, we also examined whether alcohol consumption produces selective alterations in dendritic and spine morphology in D1R MSNs in the DMS. Finally, we determined the potential contribution of our findings to alcoholdrinking behaviors.

\section{Materials and Methods}

Reagents

AMPA, picrotoxin, SCH 23390, and raclopride were obtained from Sigma. Cyclothiazide and TTX were purchased from Tocris Bioscience. Alexa Fluor 594-conjugated streptavidin was purchased from Invitrogen. All other reagents were obtained from Sigma.

\section{Animals}

Drdla-eGFP (D1-eGFP), Drd1a-tdTomato (D1-tdTomato), Drd1a-Cre (D1-Cre), Drd2-eGFP (D2-eGFP), and Drd2-cre (D2-Cre) mice were obtained from Mutant Mouse Regional Resource Centers. DsRed and C57BL/6J mice were purchased from The Jackson Laboratory. Hemizygous D1-eGFP, D2-eGFP, and D1-tdTomato mice were bred with Swiss Webster mice (Taconic). Hemizygous DsRed mice were bred with C57BL/6J mice. D1-tdTomato mice were crossed with D2-eGFP mice to obtain D1-tdTomato/D2-eGFP mice. D1-Cre or D2-Cre mice were crossed with DsRed mice to generate D1-Cre/DsRed or D2-Cre/DsRed mice, respectively. Mouse genotypes were determined by PCR analysis of products derived from tail DNA of fluorescent proteins (eGFP for D1eGFP and D2-eGFP mice; tdTomato for D1-tdTomato mice; DsRed for DsRed mice), of the Cre recombinase (D1-Cre and D2-Cre mice), or of both fluorescent proteins and the Cre recombinase (DsRed and Cre for D1-Cre/DsRed and D2-Cre/DsRed mice). Mice were housed under a $12 \mathrm{~h}$ light/dark cycle with lights on at 7:00 A.M. and food and water available ad libitum. All animal procedures in this report were approved by the Gallo Center and the University of California San Francisco
(UCSF) Institutional Animal Care and Use Committee and by the Texas A\&M University Institutional Animal Care and Use Committee. All the procedures were conducted in agreement with the Guide for the Care and Use of Laboratory Animals (National Research Council, Gallo Center) and the Association for Assessment and Accreditation of Laboratory Animal Care (AAALAC, UCSF).

\section{Preparation of solutions}

Alcohol solutions were prepared from absolute anhydrous ethyl alcohol (190 proof). For systemic administration experiments alcohol was diluted with saline $(20 \% \mathrm{v} / \mathrm{v}, 2 \mathrm{~g} / \mathrm{kg})$. For drinking experiments alcohol was diluted to $20 \%(\mathrm{v} / \mathrm{v})$ in tap water. The D1R antagonist SCH 23390 (1 $\mu \mathrm{g} / \mu \mathrm{l})$ and D2R antagonist raclopride $(8 \mu \mathrm{g} / \mu \mathrm{l})$ were dissolved in $0.9 \%$ $\mathrm{NaCl}$ (saline) solution.

\section{Systemic administration of alcohol}

The procedure was described previously by Wang et al. (2010a). Briefly, male mice ( 8 weeks) were administered alcohol or saline intraperitoneally once a day for 7 consecutive days. Sixteen hours after the seventh treatment, striatal slices containing the DMS were prepared for electrophysiological recordings.

\section{Intermittent access two-bottle choice procedure}

The procedure is described previously (Darcq et al., 2014a). Briefly, male mice ( 8 weeks) were given $24 \mathrm{~h}$ concurrent access to one bottle of $20 \%$ alcohol in water and one bottle of water starting at 12:00 P.M. on Monday, Wednesday, and Friday, with $24 \mathrm{~h}$ or $48 \mathrm{~h}$ alcohol-deprivation periods in between the alcohol-drinking sessions. The water and alcohol bottles were weighed after $24 \mathrm{~h}$ of access. Experiments started after a stable baseline of consumption was achieved $(\sim 16 \mathrm{~g} / \mathrm{kg} / 24 \mathrm{~h})$. The control group had access to two bottles of water throughout the duration of the experiment.

\section{Electrophysiology}

Slice preparation. Slice preparation was described previously (Wang et al., 2007). Briefly, coronal sections of the striatum $(220 \mu \mathrm{m})$ were cut in an ice-cold solution containing the following (in $\mathrm{mm}$ ): $40 \mathrm{NaCl}, 143.5 \mathrm{su}$ crose, $4 \mathrm{KCl}, 1.25 \mathrm{NaH}_{2} \mathrm{PO}_{4}, 26 \mathrm{NaHCO}_{3}, 0.5 \mathrm{CaCl}_{2}, 7 \mathrm{MgCl}_{2}, 10$ glucose, 1 sodium ascorbate, and 3 sodium pyruvate, saturated with $95 \% \mathrm{O}_{2}$ and $5 \% \mathrm{CO}_{2}$. Slices were then incubated in the same solution at $32^{\circ} \mathrm{C}$ for 45 min before being transferred to a chamber that contained an external solution composed of the following (in $\mathrm{mm}$ ): $125 \mathrm{NaCl}, 2.5 \mathrm{KCl}, 2.5$ $\mathrm{CaCl}_{2}, 1.3 \mathrm{MgCl}_{2}, 1.25 \mathrm{NaH}_{2} \mathrm{PO}_{4}, 25 \mathrm{NaHCO}_{3}$, and 10 glucose, saturated with $95 \% \mathrm{O}_{2}$ and $5 \% \mathrm{CO}_{2}$. Slices were stored in the external solution at room temperature until use.

Whole-cell recording. Individual slices were placed in a recording chamber and cells in the DMS were visualized using an epifluorescent microscope (Examiner A1; Zeiss). Whole-cell recordings were made using a Multiclamp 700A amplifier (Molecular Devices). Electrodes (4-6 $\mathrm{M} \Omega$ ) contained the following (in $\mathrm{mM}$ ): 115 cesium methanesulfonate, 15 HEPES, 0.6 EGTA, 8 TEA-Cl, $4 \mathrm{MgATP}$, 0.3 NaGTP, $7 \mathrm{Na}_{2} \mathrm{CrPO}_{4}$, pH $7.2-7.3$, and $1 \%$ biocytin with an osmolarity of 270-280 mOsm. AMPAinduced currents and AMPAR-mediated mEPSCs were measured as described previously (Wang et al., 2010b, 2012). Specifically, AMPA (0.2 $\mu \mathrm{M})$ was bath applied for $30 \mathrm{~s}$ in the presence of the AMPAR desensitization blocker, cyclothiazide $(100 \mu \mathrm{M})$. mEPSCs were recorded in the presence of $1 \mu \mathrm{M}$ TTX, $100 \mu \mathrm{M}$ picrotoxin, and $1.3 \mathrm{~mm}$ external $\mathrm{Mg}^{2+}$ with neurons clamped at $-70 \mathrm{mV}$. Rheobase currents $\left(I_{\text {rheobase }}\right)$ were measured under the current-clamp mode by injection of a series of 500 ms steps with increments of $10 \mathrm{pA}$. $I_{\text {rheobase }}$ was defined as the first current step capable of inducing one action potential. For current-clamp recording, the electrode contained the following (in $\mathrm{mM}$ ): 123 potassium gluconate, 10 HEPES, 0.2 EGTA, $8 \mathrm{NaCl}, 2 \mathrm{MgATP}, 0.3 \mathrm{NaGTP}, \mathrm{pH}$ $7.2-7.3$, with an osmolarity of $270-280 \mathrm{mOsm}$.

\section{Immunohistochemistry}

Tissue fixation and confocal imaging. Postrecording biocytin-staining and confocal imaging have been described previously (Wang et al., 2010b). Briefly, immediately after electrophysiology recording, DMS slices containing biocytin-filled neurons were fixed in $4 \%$ paraformaldehyde at 
$4^{\circ} \mathrm{C}$ overnight. Sections were then incubated with Alexa Fluor 594-conjugated streptavidin for $72 \mathrm{~h}$. A confocal microscope (Zeiss LSM 510) was used to image fluorescent sections. EGFP was excited by the $488 \mathrm{~nm}$ laser. TdTomato, DsRed, and Alexa Fluor 594 were excited by the $594 \mathrm{~nm}$ laser.

\section{Morphological analysis}

$3 D$ analysis of dendritic branches. Micrographs of overall dendritic branches and the soma of biocytin-filled neurons were acquired with a $40 \times$ objective at the vertical interval of $1 \mu \mathrm{m}$. Images were reconstructed in three dimensions and biocytin-filled neurons were traced using Imaris software (Bitplane). Dendritic branches were quantified with Sholl analysis (Sholl, 1953). The center of all concentric spheres is defined as the center of the soma. The starting radius was $10 \mu \mathrm{m}$ and the ending radius was $170 \mu \mathrm{m}$ from the center with an interval of $10 \mu \mathrm{m}$ between radii.

$3 D$ analysis of dendritic spines. Imaging of dendritic spines was conducted as described previously (Dumitriu et al., 2011). Specifically, dendritic branches that were $75 \mu \mathrm{m}$ away from the soma and $30 \mu \mathrm{m}$ away from the terminal point of the branches were imaged via a $100 \times$ oil-immersion objective (Zeiss, NA 1.3). The pixel size at the $X Y$ plane was $0.07 \mu \mathrm{m}$ and the interval along the $z$-axis was $0.1 \mu \mathrm{m}$. Images of spines were deconvoluted by AutoQuant X3 (Media Cybernetics) before analysis, and then a 3D perspective was rendered by the Surpass module of Imaris software package (Bitplane). The length of quantified dendrites was 45-55 $\mu \mathrm{m}$. For each of the animals examined in each group, three neurons were analyzed, and for each neuron two dendrites were analyzed. A protocol that quantifies spine density and spine types based on the Filament module of Imaris was used.

\section{Intra-DMS infusion of dopamine receptor antagonists and alcohol} intake measurements

Male C57BL/6 mice ( 9 weeks old) underwent intermittent access to 20\% alcohol as described above. To test the effect of intra-DMS infusion of the D1R or D2R antagonist on alcohol consumption, cannulae were implanted into the DMS. Mice were anesthetized with isoflurane and placed in a stereotaxic frame (David Kopf Instruments). Bilateral guide cannulae (C235G-3.0, 26 gauge; Plastics One) were aimed at the DMS at the following coordinates: $0.5 \mathrm{~mm}$ anterior to bregma, $\pm 1.5 \mathrm{~mm}$ mediolateral, $2.5 \mathrm{~mm}$ ventral to the skull surface. Cannulae were secured with stainless steel screws and dental acrylic. Stylets were inserted into the guide cannulae to keep the injector site clear of debris. After $4 \mathrm{~d}$ of recovery, the intermittent-access $20 \%$ alcohol procedure was resumed and microinfusions started when levels of alcohol intake returned to a stable baseline. Mice were infused with $0.5 \mu$ l of vehicle (saline), the D1R antagonist SCH $23390(0.5 \mu \mathrm{g})$ (Hodge et al., 1997), or the D2R antagonist raclopride $(4 \mu \mathrm{g})$ immediately before the start of drinking sessions. The injectors used for each group extended $0.5 \mathrm{~mm}$ below the tip of the cannula. Alcohol intake was measured 2, 4, and $24 \mathrm{~h}$ later.

\section{Histology}

After completion of the experiments of DMS infusion, C57BL/6 mice were anesthetized by isoflurane and perfused transcardially with $4 \%$ paraformaldehyde. For each animal, the infused area was verified in $50 \mu \mathrm{m}$ coronal sections using the Zeiss Examiner A1 epifluorescent microscope. Mice showing localized infusion in the DMS were included in the studies.
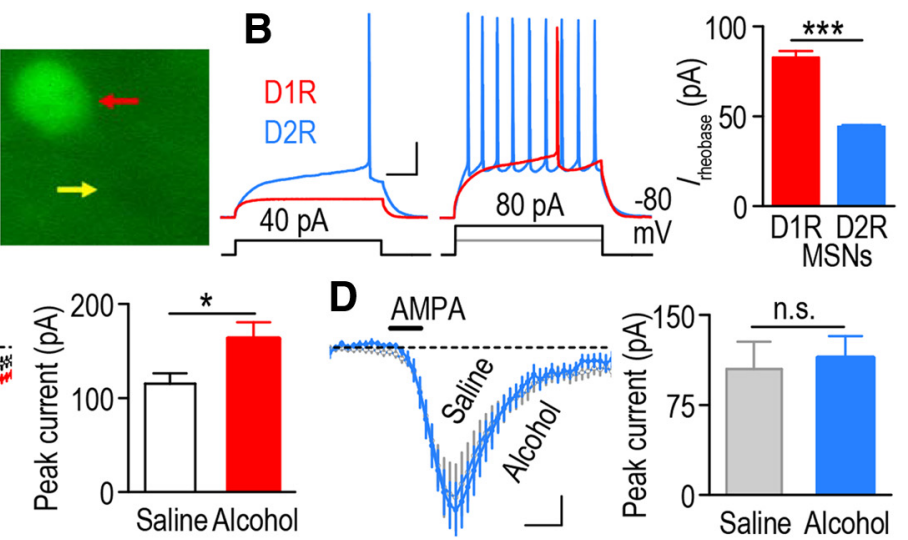

$\mathbf{F}$
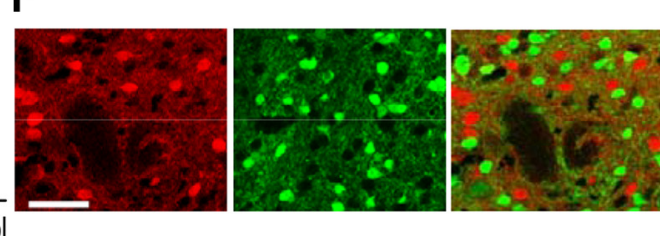

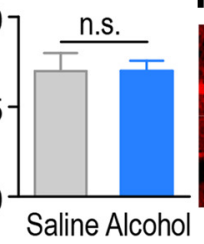$$
\text { . }
$$

Figure 1. Repeated systemicadministration of alcoholleads to along-lasting increasein AMPA-induced currentin D1R butnotD2RMSNs ofthe ( (blue) MSNs. D1RMSNs (fluorescent cells in slices from D1-eGFP mice) exhibit a greater rheobase current compared with D2RMSNs (fluorescent cells in slicesfromD2-eGFP mice). ${ }^{* *} p<0.001 ; n=3$ (D1RMSNs) and4(D2RMSNs) from two mice in each group.C, Repeated systemicadministration ically administered with alcohol $(2 \mathrm{~g} / \mathrm{kg})$ or saline once daily for 7 consecutive days. Sixteen hours after the last administration, DMS slices were prepared and AMPA-induced currents were measured. ${ }^{*} p<0.05, t$ test; $n=11$ (D1RMSNs) and 12 (D2RMSNs) cellsfrom five mice in each group. D. D1-tdTomato/D2-eGFP mice. A DMS section was imaged to show tdTomato-positive (left and right) and eGFP-positive (middle and right) neurons. Note that therewas no overlap between tdTomato and eGFP-positive neurons (right). Calibration:B, $100 \mathrm{~ms}, 20 \mathrm{mV} ; \boldsymbol{C}-\boldsymbol{E}, 0.5 \mathrm{~min}, 20 \mathrm{pA} ; \boldsymbol{F}, 50 \mu \mathrm{m}$.

\section{Statistical analysis}

All data are expressed as mean \pm SEM. Data were analyzed with an unpaired two-tailed $t$ test, one-way ANOVA, or two-way ANOVA with repeated measures, followed by the Student-Newman-Keuls (SNK) post hoc test.

\section{Results}

Repeated systemic administration of alcohol produces a long-lasting increase in AMPAR function in D1R but not D2R MSNs of the DMS

We first tested the hypothesis that alcohol alters AMPAR activity selectively in D1R but not in D2R MSNs of the DMS. To do so, we used Drd1a-eGFP (D1-eGFP) and Drd2 eGFP (D2eGFP) mice in which D1R MSNs (Fig. 1A) and D2R MSNs express the eGFP (Gong et al., 2003). As previously reported (Gertler et al., 2008), EGFP-positive neurons from D1-eGFP mice (D1R MSNs) showed higher rheobase currents than those from D2-eGFP mice (D2R MSNs; Fig. $1 B$; $t_{(5)}=11.46$, $p<0.001)$ indicating that these two populations of neurons were recorded separately. D1-eGFP and D2-eGFP mice were systemically administered with saline or a nonhypnotic dose of alcohol ( $2 \mathrm{~g} / \mathrm{kg})$ once a day for 7 consecutive days, and AMPAR activity in DMS D1R and D2R MSNs was measured $16 \mathrm{~h}$ after the last administration of alcohol. As shown in Figure $1 C$, alcohol enhanced AMPA-induced currents in the DMS D1R MSNs of D1-eGFP mice $\left(t_{(21)}=-2.23 ; p<0.05\right)$. In contrast, the AMPA currents were identical in DMS D2R MSNs of alcohol- and saline-treated D2-eGFP mice (Fig. 1D; $\left.t_{(20)}=-0.31 ; p>0.05\right)$. In addition, we did not detect differ- 

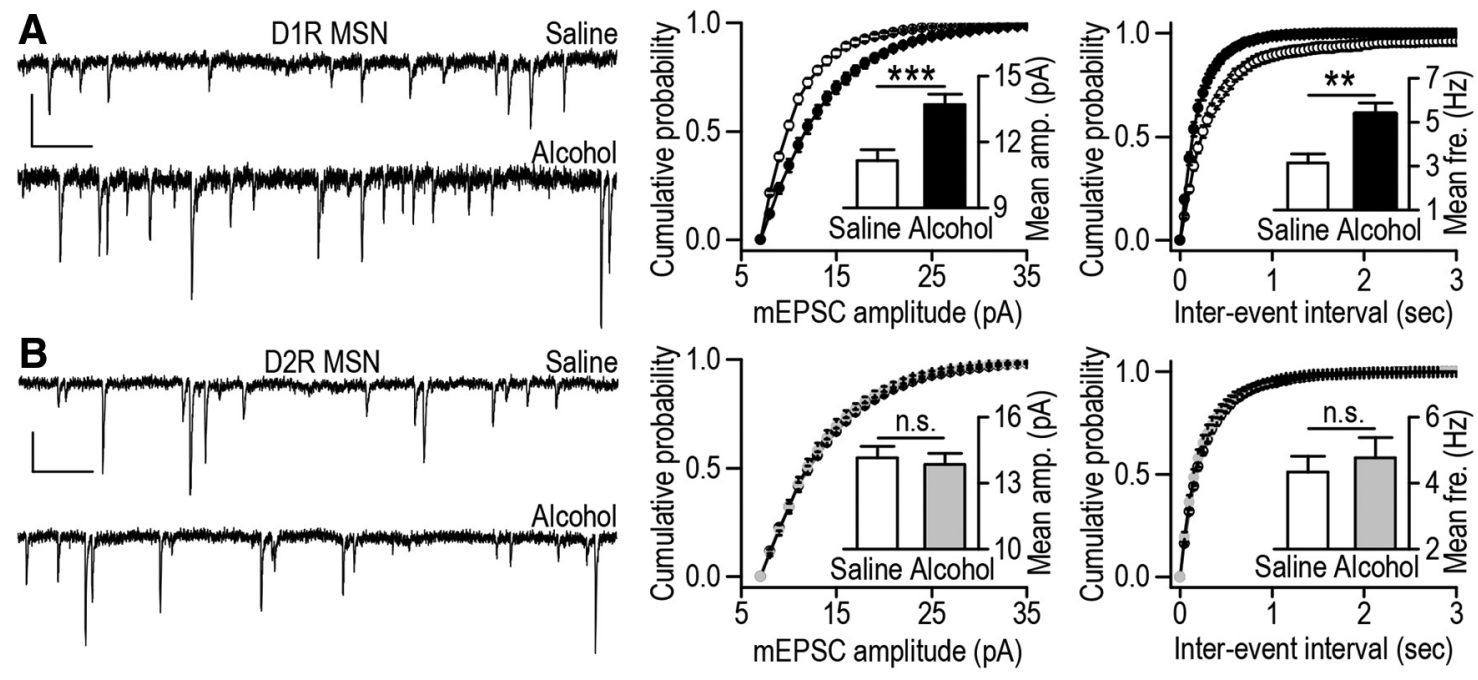

Figure 2. Repeated systemic administration of alcohol induces a long-lasting increase in synaptic AMPAR function in D1R but not D2R MSNs of the DMS. D1-eGFP and D2-eGFP mice were treated and DMS slices were prepared as above; AMPAR-mediated mEPSCs were recorded in fluorescent neurons in D1-eGFP (D1R MSNs) and D2-eGFP (D2R MSNs) mice. A, Systemic alcohol administration causes a long-lasting increase in the amplitude and frequency of AMPAR-mEPSCs in DMS D1R MSNs. Left, Sample traces of mEPSCs. Middle, Cumulative probability plots for mEPSC amplitude. Inset, Bar graphs comparing the mean mEPSC amplitude for saline and alcohol groups; ${ }^{* *} p<0.001, t$ test. Right, Cumulative probability plots for mEPSC interevent interval from saline- and alcohol-administered mice. Inset, Mean mEPSC frequency; ${ }^{* *} p<0.01, t$ test; $n=14$ (D1R MSNs) and 20 (D2R MSNs) cells from four to five mice. $\boldsymbol{B}$, Systemic alcohol administration does not alter the amplitude or the frequency of AMPAR-mediated mEPSCs in D2R MSNs of the DMS. Left, Sample traces of mEPSCs. Middle, Cumulative probability plots for mEPSC amplitude for saline- and alcohol-treated mice. Inset, Bar graphs comparing the mean amplitudes of mEPSCs from saline and alcohol groups. Right, Cumulative probability plots for mEPSC interevent interval from saline- and alcohol-administered mice. Inset, Mean frequency of mEPSCs for saline and alcohol groups; $n=18$ (D1R MSNs) and 20 (D2R MSNs) cells from six mice for each group. Calibration: $A, B, 0.3 \mathrm{~s}, 10 \mathrm{pA}$.

A

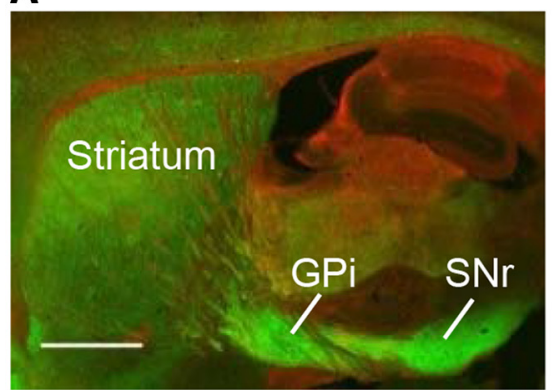

B

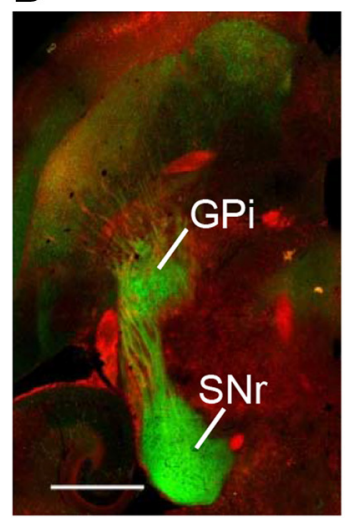

D

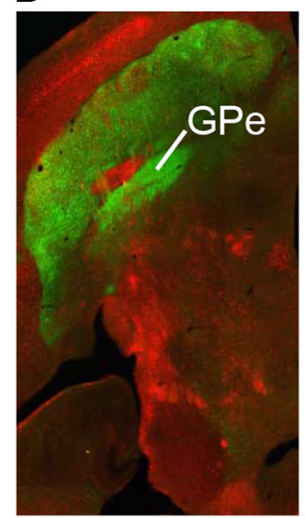

C

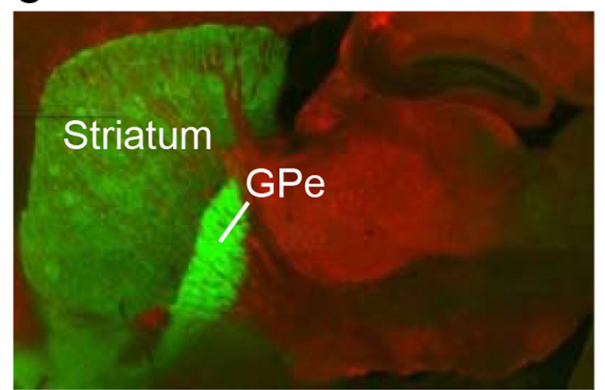

E

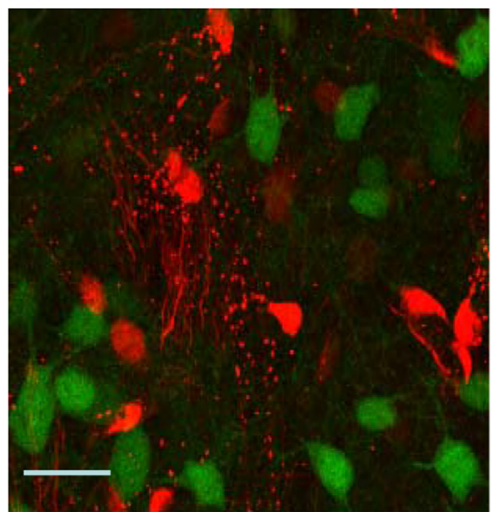

Figure 3. Generation of two new lines of mice that express eGFP in D1R or D2R MSNs in the striatum. D1-Cre mice and D2-Cre mice were crossed with a Cre-reporter line, DsRed, to generate D1-Cre/DsRed mice and D2-Cre/DsRed mice, respectively. DsRed mice express a red fluorescent protein, which is replaced by eGFP following Cre-recombination in D1-Cre/ DsRed or D2-Cre/DsRed mice. $\boldsymbol{A}-\boldsymbol{D}$, Distinct projection targets of DMS D1R and D2R MSNs. Images from sagittal $(\boldsymbol{A}, \boldsymbol{C})$ and horizontal $(\boldsymbol{B}, \boldsymbol{D})$ sections from D1-Cre/DsRed $(\boldsymbol{A}, \boldsymbol{B})$ and D2-Cre/DsRed $(\boldsymbol{C}, \boldsymbol{D})$ mice. Note that D1R MSNs project to the GPi and the $\operatorname{SNr}(\boldsymbol{A}, \boldsymbol{B})$, whereas D2R MSNs project to the GPe $(\boldsymbol{C}, \boldsymbol{D})$. $\boldsymbol{E}$, A sample high-power image of D1R MSNs (eGFP-positive neurons) in a section from D1-Cre/DsRed mouse. Scale bars: $\boldsymbol{A}, \boldsymbol{B}, 1 \mathrm{~mm} ; \boldsymbol{E}, 20 \mu \mathrm{m}$.

ences in AMPA current in nonfluorescent MSNs in alcohol- and salinetreated D1-eGFP mice (Fig. $1 E ; t_{(22)}=$ $-0.01 ; p>0.05)$. Since there is little overlap between D1R MSNs and D2R MSNs in the dorsal striatum (Fig. 1F; Bertran-Gonzalez et al., 2008), it is highly likely that eGFP-negative MSNs in the D1-GFP mice are D2R MSNs. These results suggest that alcohol produces a long-lasting increase in AMPAR function in D1R but not D2R MSNs of the DMS.

The AMPA-induced current measures the activity of both synaptic and extrasynaptic AMPARs (Arendt, 2001). To determine whether synaptic AMPAR function is altered selectively in D1R MSNs, we recorded AMPAR-mediated mEPSCs in DMS D1R MSNs and D2R MSNs from alcohol- and saline-treated D1-eGFP and D2-eGFP mice. We found that the amplitude of mEPSCs was greater in DMS D1R MSNs from alcohol-treated D1-eGFP mice than their saline controls (Fig. $2 A$, left and middle; $t_{(32)}=-3.71, p<0.001$ ), whereas the mEPSC amplitudes in D2R MSNs were identical in slices from alcohol- and saline-treated mice (Fig. 2B, left and middle; $\left.t_{(36)}=0.41, p>0.05\right)$. Interestingly, the mEPSC frequency was also higher in D1R MSNs, but not D2R MSNs, from the alcohol group than the 
saline group (D1R MSNs: Fig. $2 A$, left and right; $t_{(32)}=-3.22$; $p<0.01$; D2R MSNs: Fig. $2 B$, left and right; $t_{(36)}=-0.56 ; p>$ $0.05)$. These results indicate that repeated exposure to alcohol leads to a long-lasting enhancement of synaptic AMPAR function selectively in D1R but not D2R MSNs of the DMS.

\section{Generation and characterization of D1-Cre/DsRed and D2-Cre/DsRed mice}

Next, we aimed to determine whether alcohol consumption enhanced AMPAR function selectively in D1R MSNs of the DMS.
To do so, we generated two new lines of mice that consume high levels of alcohol and in which D1R MSNs or D2R MSNs are fluorescently labeled. Since C57BL/6 mice consume large quantities of alcohol, we crossed Drd1a-Cre (D1-Cre) and Drd2-Cre (D2-Cre) mice with a Crereporter line DsRed (Gong et al., 2007; De Gasperi et al., 2008), all of which are on the C57BL/6 background, and generated two new lines of mice: D1-Cre/DsRed and D2-Cre/DsRed mice. The DsRed line expresses a red fluorescent protein, which is switched to eGFP following Cre-mediated recombination when the DsRed mice are bred with Cre lines (De Gasperi et al., 2008). As shown in Figure 3, $A$ and $B$, D1R MSNs in D1-Cre/DsRed mice are eGFP positive and the axonal fibers of eGFPlabeled neurons are detected in the internal segment of the GPi and in the $\mathrm{SNr}$, the target of D1R MSNs (Gerfen et al., 2013). Similarly, D2R MSNs in the D2Cre/ DsRed mice are eGFP positive and their axonal fibers project to the external segment of the GPe (Fig. 3C,D). As shown in Table 1, D1-Cre/DsRed and D2-Cre/ DsRed mice consumed high levels of alcohol and exhibited a high preference for alcohol. The levels of alcohol consumption in D1-Cre/DsRed and D2-Cre/ DsRed mice were identical (Table 1; $t_{(34)}=0.14 ; p>0.05$ ), as was the alcohol preference (Table 1; $\left.t_{(34)}=-0.98 ; p>0.05\right)$.

\section{Alcohol consumption induces \\ long-lasting increases in synaptic AMPAR function in DMS D1R but not D2R MSNs}

Next, D1-Cre/DsRed and D2-Cre/DsRed mice consumed alcohol for 8 weeks (Table 1) and AMPAR activity was measured in the eGFP-positive DMS neurons (Fig. 3E) $24 \mathrm{~h}$ after the last alcohol drinking session. We found that AMPA-induced current was significantly higher in DMS D1R MSNs of alcohol-consuming D1Cre/DsRed mice as compared with water-only drinking mice (Fig. $4 A ; t_{(33)}=-2.96, p<0.01$ ). In contrast, AMPAR activity was similar in DMS D2R MSNs of D2-Cre/DsRed mice drinking alcohol versus water (Fig. $4 B ; t_{(40)}=1.26, p>0.05$ ). We also compared the synaptic AMPAR function between the alcohol and water groups. Consistent with the results of AMPA-induced currents, we found that the amplitude of AMPAR-mediated mEPSCs was higher in DMS D1R MSNs of alcohol-drinking D1Cre/DsRed mice than water controls (Fig. $4 C$; $t_{(28)}=-3.96, p<$ $0.001)$. In contrast, the mEPSC amplitudes were identical in DMS
Table 1. Comparison of levels of alcohol consumption and of alcohol preference in transgenic mice used

\begin{tabular}{llll}
\hline Mouse lines & Alcohol intake $(\mathrm{g} / \mathrm{kg} / 24 \mathrm{~h})$ & Alcohol preference $(\%)$ & \\
\hline D1-eGFP & $4.90 \pm 0.50$ & $27.88 \pm 3.49$ & $n=11$ \\
D1-Cre/DsRed & $16.08 \pm 1.23^{* * *}$ & $53.69 \pm 3.48^{\# \# \#}$ & $n=17$ \\
D2-Cre/DsRed & $15.88 \pm 0.75^{a}$ & $57.52 \pm 1.97^{b}$ & $n=19$ \\
\hline
\end{tabular}

All mice were exposed to alcohol using the intermittent access to $20 \%$ alcohol two-bottle choice drinking procedure ${ }^{* * *} p<0.001$, D1-Cre/DsRed versus D1-eGFP mice for alcohol intake; \#\# $p<0.001$, D1-Cre/DsRed versus D1-eGFP mice for alcohol preference. ${ }^{a}$ No significant difference $(p>0.05)$ in alcohol intake between D1-Cre/DsRed and D2Cre/DsRed mice. ${ }^{b}$ No significant difference $(p>0.05)$ in alcohol preference between D1-Dre/DsRed and D2-Cre/ DsRed mice.
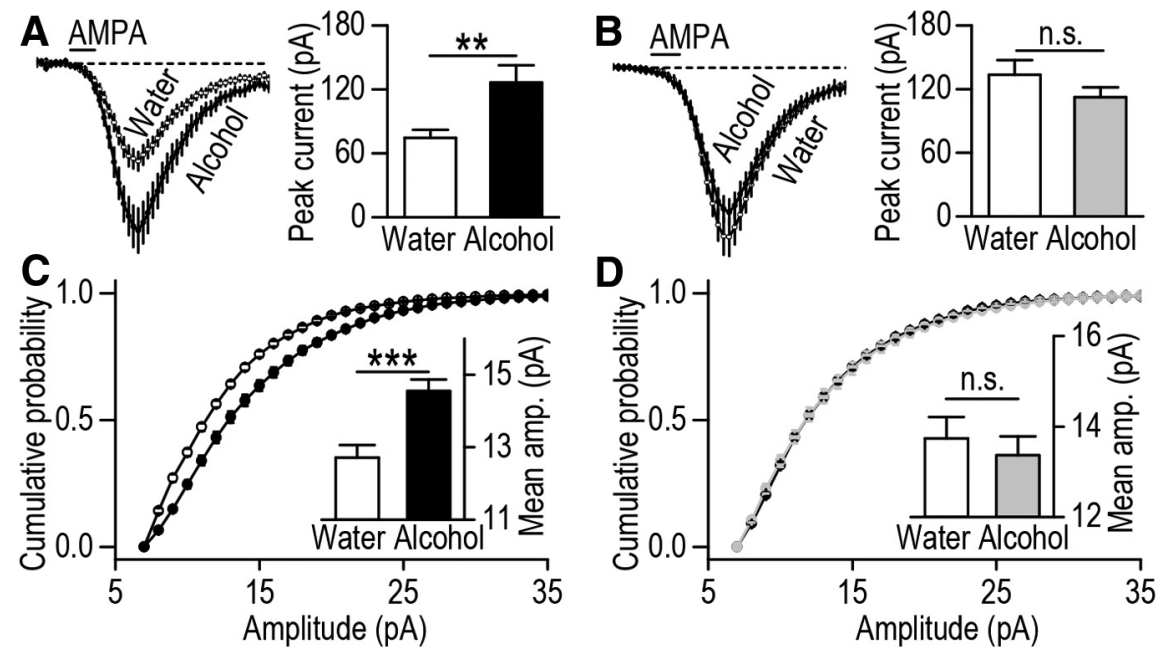

Figure 4. Alcohol consumption induces a long-lasting increase in AMPAR activity in D1R but not D2R MSNs of the DMS D1-Cre/DsRed and D2-Cre/DsRed mice consumed 20\% alcohol or water only for 8 weeks using the intermittent-access two-bottle

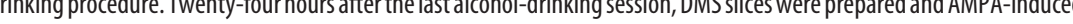
plitudes in water (open circles) and alcohol (closed circles) groups show a shift of the distribution of amplitudes to the right after alcohol consumption. Inset, Bar graphs summarizing mean values of mEPSC amplitude in water and alcohol groups; ${ }^{* * *} p<0.001$, $t$ test; $n=15$ cells from four mice for each group. $D$, Alcohol consumption does not alter the amplitude of AMPAR-mEPSCs in D2R MSNs of the DMS; $n=20$ (D1R MSNs) and 22 (D2R MSNs) cells from five mice for each group.

D2R MSNs of alcohol and water groups (Fig. $4 D ; t_{(40)}=-0.07$, $p>0.05)$. These results suggest that repeated cycles of alcohol consumption and abstinence produce a long-lasting increase in synaptic AMPAR activity selectively in DMS D1R but not D2R MSNs.

\section{Alcohol consumption increases dendritic complexity of D1R but not D2R MSN of the DMS}

Because AMPAR activity is increased by alcohol in DMS D1R MSNs and AMPAR plasticity is associated with morphological changes in neurons (Kasai et al., 2010), we examined whether the complexity of dendritic arborization was altered by alcohol consumption in the DMS of D1R but not D2R MSNs. D1-Cre/DsRed and D2-Cre/DsRed mice underwent the same paradigm described above. Twenty-four hours after the last alcohol drinking session, the neuronal tracer biocytin was applied through the patching pipette into DMS D1R and D2R MSNs, and biocytinlabeled neurons were imaged using confocal microscopy (Fig. $5 A$ ). The number of dendritic processes was measured by a Sholl analysis in concentric spheres centered on the soma (Fig. 5B). As shown in Figure $5 C$, dendrites that were $40-120 \mu \mathrm{m}$ from the 
A

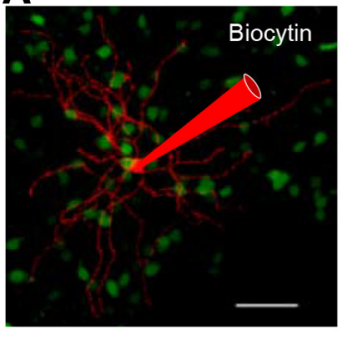

E

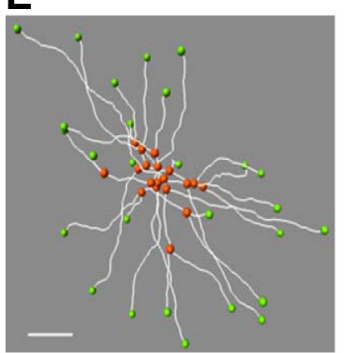

I

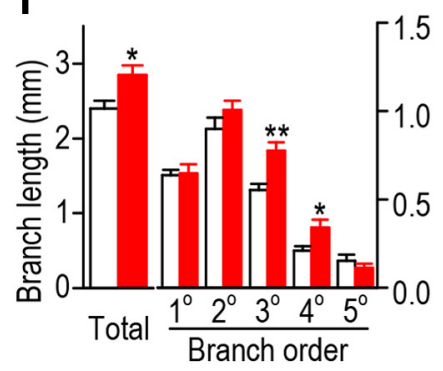

B

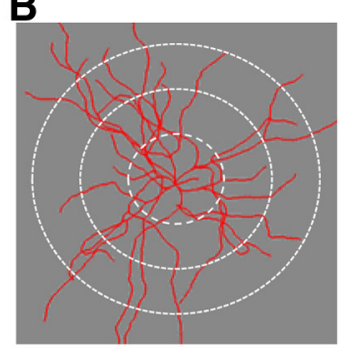

$\mathbf{F}$

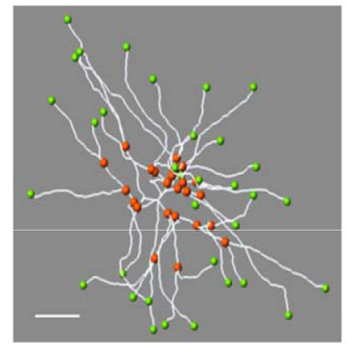

J

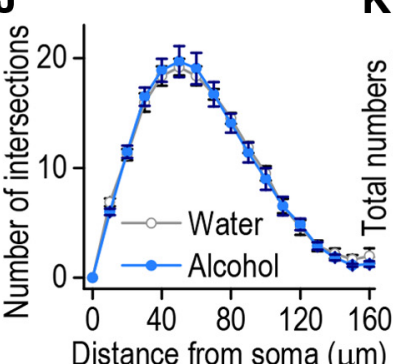

C

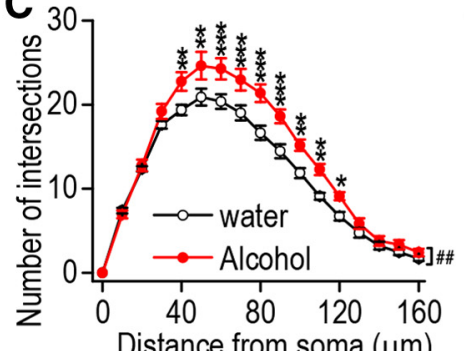

G

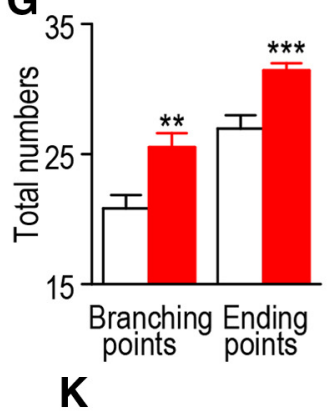

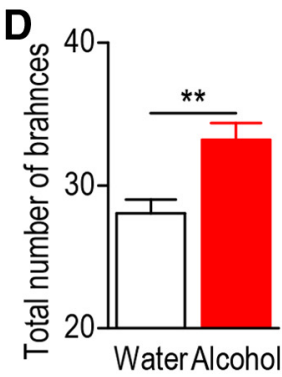

$\mathrm{H}$

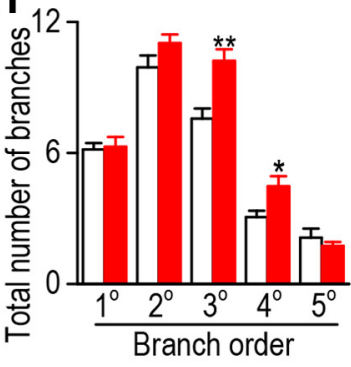

$\mathbf{L}$
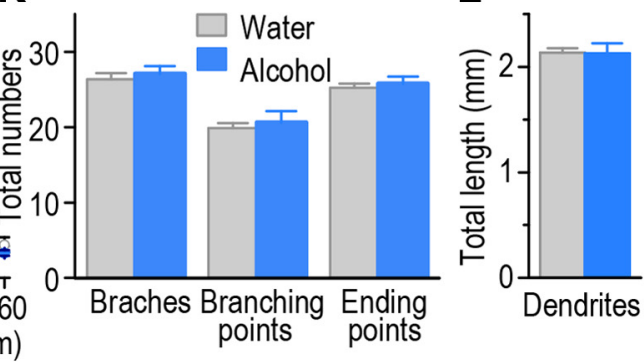

Figure 5. Alcohol consumption leads to increases in dendritic branches and length of D1R MSNs in the DMS. D1-Cre/DsRed and D2-Cre/DsRed mice consumed alcohol and DMS slices were prepared as above. Biocytin (1\%) was perfused into eGFP-positive D1R or D2R MSNs via the whole-cell patch pipette, and slices were then fixed by 4\% PFA and stained for biocytin-filled neurons. $\boldsymbol{A}$, A sample image of a biocytin-filled D1R MSN and its dendritic branches (red) in the DMS of a D1-Cre/DsRed mouse. Scale bar, $50 \mu \mathrm{m}$. $\boldsymbol{B}$, Automated three-dimensional reconstruction of the biocytin-filled cell in $\boldsymbol{A}$. The radial grids indicate the radii of Sholl analysis. For the actual analysis, radii increased in a $10 \mu \mathrm{m}$ interval. $\boldsymbol{C}$, A three-dimensional Sholl analysis of biocytin-filled and reconstructed neurons reveals significantly more intersections of dendritic process at $40-120 \mu \mathrm{m}$ from the cell body of D1R MSNs after alcohol consumption. ${ }^{\# \#} p<0.01$, two-way RM-ANOVA; ${ }^{*} p<0.05,{ }^{* *} p<0.01,{ }^{* * *} p<0.001$, SNK test; $n=8$ (Water) and 11 (Alcohol) mice. D, Alcohol consumption produces an increase in the total number of dendritic branches; ${ }^{* *} p<0.01$ versus the water group; $n=8$ (Water) and 11 (Alcohol) mice. $\boldsymbol{E}, \boldsymbol{F}$, A representative image depicting reconstructed dendritic branches of a D1R MSN from the water $(\boldsymbol{E})$ and alcohol $(\boldsymbol{F})$ groups. Red and green points show branching and ending points of dendritic branches, respectively. Scale bar, $40 \mu \mathrm{m}$. $\mathbf{G}$, Alcohol consumption leads to increases in the numbers of branching and ending points; ${ }^{* *} p<0.01$ and ${ }^{* * *} p<0.001$ versus the water group; $n=8$ (Water) and 10 (Alcohol) mice. $\boldsymbol{H}$, Alcohol consumption produces an increase in the number of tertiary $\left(3^{\circ}\right)$ and quaternary $\left(4^{\circ}\right)$ branches; ${ }^{*} p<0.05$ and ${ }^{* *} p<0.01$ versus the water group; $n=8$ (Water) and 10 (Alcohol) mice. I, Alcohol consumption leads to an increase in the length of dendritic branches. The total dendritic length (left) and the total length of tertiary $\left(3^{\circ}\right)$ and quaternary $\left(4^{\circ}\right)$ branches were higher in the alcohol group than in their water controls; ${ }^{*} p<0.05$ and ${ }^{* *} p<0.01$ versus the water group; $n=8$ (Water) and 10 (Alcohol) mice. J, Alcohol consumption does not produce a detectable change in Sholl interactions in D2R MSNs of the DMS; $n=8$ (Water) and 10 (Alcohol) mice. $\boldsymbol{K}$, Alcohol consumption does not induce a significant change in the total number of dendritic branches, branching points, or ending points in D2R MSNs of the DMS; $n=8$ (Water) and 9 (Alcohol) mice. $L$, Alcohol consumption does not alter the total dendritic length in D2R MSNs of the DMS; $n=8$ (Water) and 9 (Alcohol) mice.

soma exhibited more intersections in DMS D1R MSNs from alcohol-drinking D1-Cre/DsRed mice than that in water controls $\left(F_{(1,17)}=11.12, p<0.01\right)$. Furthermore, the total number of dendritic branches of DMS D1R MSNs was significantly higher in alcohol-drinking animals than in water controls (Fig. $5 D ; t_{(16)}=$ $-3.30, p<0.01)$. We also observed that the total branching points and the total ending points in DMS D1R MSNs were increased following alcohol consumption (Fig. $5 E-G ; t_{(16)}=$ $-3.10, p<0.01$ for the branching points; $t_{(16)}=-4.02, p<$ 0.001 for the ending points). Based on the number of bifurcations from the cell body, dendritic branches of striatal MSNs can be divided into different orders of branches: primary, secondary, tertiary, and so forth (Gertler et al., 2008). Thus, we examined whether alcohol consumption alters the number of dendritic branches within the different orders. As shown in Figure $5 H$, the numbers of the tertiary and quaternary dendritic branches in DMS D1R MSNs were significantly higher in alcohol-drinking animals than in their water controls $\left(t_{(16)}=-3.61, p<0.01\right.$ tertiary branching; $t_{(16)}=-2.40, p<0.05$ quaternary branching). Moreover, the total dendritic length and the total length of the tertiary and quaternary dendritic branches in DMS D1R MSNs were also significantly higher in alcohol-drinking animals than in their water controls (Fig. 5I; $t_{(16)}=-2.58, p<0.05$ total number of branches; $t_{(16)}=-3.53, p<0.01$ tertiary branches; $t_{(16)}=-2.37, p<0.05$ quaternary branches). These results indicate that alcohol consumption increases the arborization of the tertiary and quaternary dendritic branches in DMS D1R MSNs.

In contrast, when the dendritic morphology of DMS D2R MSNs was compared between the alcohol and water D2Cre/DsRed mice, we did not detect a significant difference in the number of Sholl intersections (Fig. 5J; $F_{(1,16)}=0.01, p>0.05$ ), the total number of dendritic branches (Fig. $5 K ; t_{(15)}=-0.46$, $p>0.05$ ), the total number of branching points (Fig. $5 K ; t_{(15)}=$ $-0.70, p>0.05)$, the total number of branching ending points (Fig. $5 K ; t_{(15)}=-0.52, p>0.05$ ), or the total dendritic length (Fig. $\left.5 L ; t_{(15)}=0.04, p>0.05\right)$. These results reveal that the 
alterations in dendritic complexity by alcohol in the DMS are specific for D1R MSNs.

\section{Alcohol consumption increases the density of mushroom spines in D1R but not D2R MSNs of the DMS}

Alcohol-induced, long-term synaptic plasticity of AMPAR-mediated transmission can be associated with structural plasticity of dendritic spines (Russo et al., 2010). Thus, we examined whether the density of dendritic spines was altered by alcohol consumption in DMS D1R MSNs. Twenty-four hours after the last session of alcohol consumption, biocytin was infused into DMS D1R or D2R MSNs of alcohol-drinking D1-Cre/DsRed and D2Cre/DsRed mice or water controls, and the spine density of biocytin-filled neurons was measured (Fig. 6A,B). Although the total spine density in DMS D1R MSNs (Fig. $6 C, D ; t_{(15)}=0.45, p>0.05$ ) or DMS D2R MSNs (Fig. $6 E ; t_{(13)}=0.40, p>0.05$ ) was not different between alcohol- and water-drinking D1-Cre/DsRed mice, the density of mature, mushroom-shaped spines in D1R MSNs was higher in the alcohol group than in the water group (Fig. $\left.6 C, F ; t_{(15)}=-2.51, p<0.05\right)$. Furthermore, the density of immature, long-thin spines in the DMS D1R MSNs was lower in alcohol-drinking D1-Cre/DsRed mice as compared with water controls (Fig. $\left.6 C, F ; t_{(15)}=2.15, p<0.05\right)$. In contrast, the density of mushroom spines (Fig. $6 G$; $\left.t_{(13)}=0.07, p>0.05\right)$ and the density of long-thin spines (Fig. $6 G ; t_{(13)}=0.3, p>$ $0.05)$ were similar in the DMS D2R MSNs of alcohol- and water-drinking D2-Cre/DsRed mice. These results suggest that while alcohol consumption does not alter the total spine density, they stimulate spine maturation from the long-thin to mushroom spines specifically in D1R MSNs but not in D2R MSNs of the DMS.

\section{Inhibition of D1Rs in the DMS attenuates alcohol consumption}

Our results suggest that repeated exposure of mice to alcohol produces long-lasting increases in AMPAR activity, dendritic complexity, and density of mushroom spines specifically in D1R MSNs. In vivo alcohol exposure elevates levels of striatal dopamine (Gonzales et al., 2004; Sulzer, 2011), which activates D1Rs in D1R MSNs that may contribute to the functional and structural plasticity and consequently alcohol consumption. Therefore to assess whether the D1R is required for alcohol consumption, we bilaterally infused the D1R antagonist SCH 23390 $(0.5 \mu \mathrm{g} / 0.5 \mu \mathrm{l} / \mathrm{side}$; Hodge et al., 1997) or vehicle (saline) into the DMS of C57BL/6 mice and measured alcohol intake at 2, 4, and $24 \mathrm{~h}$ after the start of the drinking session. We found that alcohol intake during the 2 and $4 \mathrm{~h}$ but not $24 \mathrm{~h}$ drinking sessions was significantly lower following SCH 23390 infusion than following vehicle infusion (Fig. $7 A ; F_{(1,19)}=11.61, p<0.01$; Fig. $7 B, F_{(2,38)}$ $=14,99, p<0.001 ; q=5.01, p<0.01$ at $2 \mathrm{~h}, q=3.68, p<0.05$ at $4 \mathrm{~h}, q=1.15, p>0.05$ at $24 \mathrm{~h}$ ), and alcohol intake was significantly less at $2 \mathrm{~h}$ than at $4 \mathrm{~h}$ following SCH 23390 infusion (Fig. $7 B ; q=3.65, p<0.05)$. The reduction of alcohol intake was accompanied by a decrease in alcohol preference (Fig. $7 C ; F_{(1,19)}$ $=6.12, p<0.05$ ). Water intake at the $2 \mathrm{~h}$ time point was not significantly different between the SCH 23390 and vehicle groups (Fig. $7 D ; F_{(1,19)}=0.01, p>0.05$ ). We also assessed whether inhibition of D2Rs in the DMS alters alcohol consumption. The D2R antagonist raclopride $(1 \mu \mathrm{g})$ has been shown in the nucleus accumbens (Hodge et al., 1997) and the dorsolateral striatum (Corbit et al., 2014) to alter behavioral response for alcohol. To ensure D2Rs in the DMS are inhibited, a higher dose of raclopride ( $4 \mu \mathrm{g} / 0.5 \mu \mathrm{l} / \mathrm{side}$ ) was bilaterally infused into the DMS and alcohol intake was measured. We found that raclopride infusion did not alter alcohol intake (Fig. 7A; $F_{(1,20)}=1.36, p>0.05$ ), alcohol preference (Fig. $7 C$; $\left.F_{(1,20)}=0.95, p>0.05\right)$, or water intake (Fig. $7 D ; F_{(1,20)}=$ $0.13, p>0.05)$. These results suggest that activation of D1Rs is required for mechanisms underlying alcohol consumption.

\section{Discussion}

In this study we report that repeated systemic alcohol administration, or cycles of alcohol consumption and withdrawal, increase AMPAR activity in DMS D1R but not D2R MSNs. 

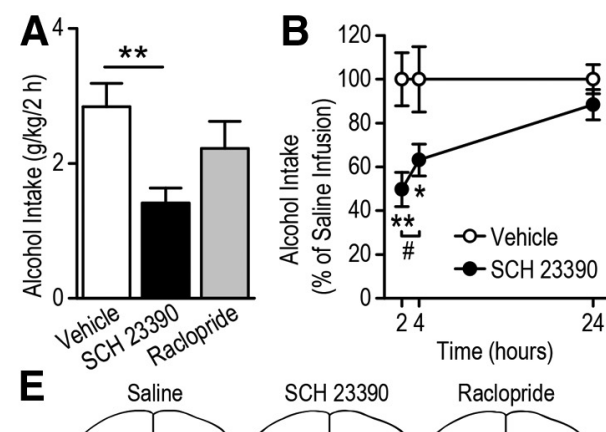

SCH 23390

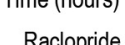

$F$

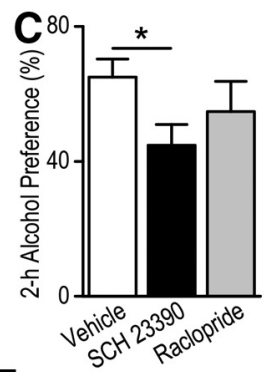

$F$

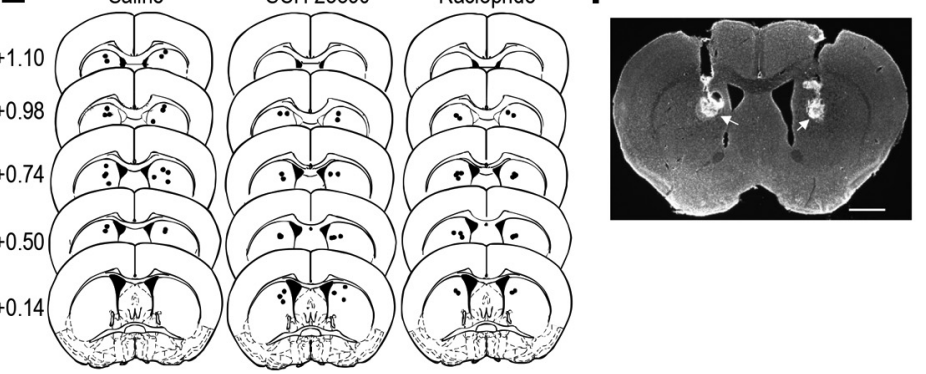

$+0.50$

$+0.14$

Figure 7. Intra-DMS infusion of a D1R antagonist causes a reduction of alcohol consumption. The D1R antagonist SCH 23390 $(0.5 \mu \mathrm{g}), \mathrm{D} 2 \mathrm{R}$ antagonist raclopride $(4 \mu \mathrm{g})$, or vehicle (saline) was bilaterally infused into the DMS of C $57 \mathrm{BL} / 6$ mice 5 min before the start of a drinking session, and alcohol intake was measured 2, 4, and $24 \mathrm{~h}$ later. $\boldsymbol{A}$, Intra-DMS infusion of SCH 23390, but not of raclopride, leads to a decrease in $2 \mathrm{~h}$ alcohol-drinking session; ${ }^{* *} p<0.01$, one-way ANOVA. $\boldsymbol{B}, \mathrm{SCH} 23390$ infusion causes a time-dependent reduction in alcohol intake; ${ }^{* *} p<0.01$ versus Vehicle at $2 \mathrm{~h} ;{ }^{*} p<0.05$ versus Vehicle at $4 \mathrm{~h}$; ${ }^{\#} p<0.05$, tw0-way RM-ANOVA followed by SNK tests. C, Intra-DMS infusion of SCH 23390, but not raclopride, produces a decrease in preference for $2 \mathrm{~h}$ alcohol intake; ${ }^{*} p<0.05$, one-way ANOVA. $\boldsymbol{D}$, Intra-DMS infusion of SCH 23390 or of raclopride does not alter $2 \mathrm{~h}$ water intake. $\boldsymbol{E}$, Schematic representation of the injection cannula placements. The location of the injector tips is represented by black circles for Vehicle (left), SCH 23390 (middle), and raclopride (right) infusions. F, Sample image showing the placement of injection cannulae as indicated by arrowheads. Scale bar, $1 \mathrm{~mm} . n=11$ (Vehicle), 10 (SCH 23390), and 11 (raclopride).

Furthermore, we show that alcohol consumption increases the number and length of specific tertiary and quaternary dendrites and the density of mushroom spines in D1R but not D2R MSNs of the DMS. Importantly, we found that inhibition of D1R function in the DMS causes a reduction of alcohol consumption. Our data suggest that alcohol triggers a cell type-specific functional and structural plasticity in the DMS, contributing to mechanisms that drive alcohol consumption.

Previously we reported that alcohol enhances the induction of NMDAR-dependent LTP of AMPAR-mediated response in the DMS (Wang et al., 2010a; 2012), and here we show that alcohol exposure produces a long-lasting increase in mEPSC amplitude, indicating persistent facilitation of AMPAR activity. The AMPAR facilitation occurs specifically in D1R MSNs of the DMS. In line with this observation, dopamine signaling was shown to be essential for LTP induction in D1R but not D2R MSNs (Shen et al., 2008). In fact, D1R signaling in the dorsal striatum stimulates LTP induction (Calabresi et al., 2007), whereas dopamine activation of D2Rs inhibits NMDAR activity (Kotecha et al., 2002). In vivo alcohol exposure induces elevation of dopamine levels in the striatum (Gonzales et al., 2004; Sulzer, 2011). Thus, our results suggest that alcohol, via NMDAR facilitation and dopaminemediated activation of D1Rs, stimulates LTP induction in D1R MSNs. In contrast, alcohol-mediated facilitation of NMDAR activity is counteracted in D2R MSNs by the D2R inhibition of the NMDARs, which may underlie no change in synaptic plasticity of AMPAR response in this subpopulation of neurons. We found that exposure of mice to alcohol also increases the frequency of mEPSCs in D1R MSNs of the DMS. An increase in mEPSC frequency may result from the increased number of dendritic spines where glutamatergic synapses are located (Kerchner and Nicoll,

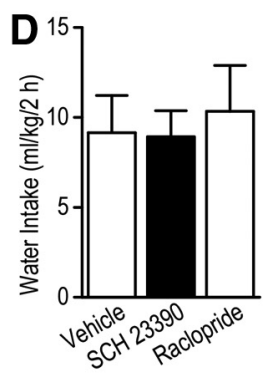

2008). In fact, alcohol consumption increased the total dendritic length of DMS D1R MSNs without altering the total spine density of the neurons, which presumably results in elevation of the number of spines. All spines form synaptic contact (Honkura et al., 2008), thus, alcohol consumption is likely to produce an increased number of synapses in DMS D1R MSNs and consequently account for the enhanced mEPSC frequency in D1R MSNs in response to alcohol exposure.

Alcohol consumption also increased tertiary and quaternary dendrites of D1R MSNs but not in D2R MSNs in the DMS, which may be the result of different afferent inputs into D1R versus D2R MSNs. Specifically, Wall et al. (2013) recently reported that D1R MSNs receive projections preferentially from sensory cortical and limbic structures including both limbic cortex and amygdala, whereas D2R MSNs receive innervations mainly from the motor cortex (Wall et al., 2013). Therefore, these brain regions may selectively affect D1R or D2R MSN activity via acting on specific dendritic branches of these two neuron populations. It will be of interest to determine whether different inputs target different orders of dendrites of D1R MSNs versus D2R MSNs and whether synaptic transmission at these inputs are distinctly altered by alcohol. Interestingly, alcohol consumption does not alter all orders of dendritic branches: only tertiary and quaternary dendritic branches in DMS D1R MSNs are increased in number and length following in vivo alcohol exposure. The underlying mechanism for the observed increase in dendritic branches that are located $40 \mu \mathrm{m}$ away from the soma is yet to be determined. This may be due to the fact that glutamatergic inputs form synapses on dendrites over $30 \mu \mathrm{m}$ from the soma (Wilson, 2004). The lack of excitatory synapses in the proximal dendrites may also contribute to the lack of changes in the primary and secondary dendritic branches following alcohol consumption. Finally, it is important to note that primary dendrites also remain unchanged in dopamine D2R-overexpressing mice that exhibit similar dendritic complexity (Cazorla et al., 2012).

Recently, Spiga et al. (2014) reported that passive vapor chamber exposure to alcohol reduces the density of immature longthin spines but not of mature mushroom spines in the NAc. Interestingly, we found that alcohol consumption increases the density of mature mushroom spines, whereas the density of immature long-thin spines is decreased in D1R MSNs of the DMS. These results suggest that alcohol stabilizes transient immature spines into more permanent functional spines, a process that occurs through an activity-dependent mechanism (Tada and Sheng, 2006). For example, stimulation protocols that induce LTP are associated with enlargement of existing spines (Kasai et al., 2010). Thus, it is plausible that the induction of LTP by alcohol (Wang et al., 2012) may underlie the structural plasticity of spines in D1R MSNs. Specifically, enlargement of spines from the long-thin to mushroom type is associated with increased func- 
tional expression of AMPARs (Kasai et al., 2010), and we found that excessive alcohol consumption increases synaptic localization of the AMPAR subunits GluR1 and GluR2 (Wang et al., 2012), resulting in a long-lasting increase in synaptic AMPAR receptor activity (Wang et al., 2012). Thus, the increased synaptic localization and increased function of AMPARs is likely to contribute to the enlargement of spines from the long-thin to mushroom type. Together, the increased branches (thus increased total number of spines) and the switch of immature to mature spines that are induced by alcohol consumption may enhance the activity of D1R MSNs in the direct pathway.

Activation of D1R MSNs and D2R MSNs yields opposing effects on addiction-related behaviors (Lobo et al., 2010; Ferguson et al., 2011; but see Cui et al., 2013), and exposure to cocaine was found to distinctly alter D1R and D2R MSN activities in mouse NAc (Bock et al., 2013; Pascoli et al., 2014). Furthermore, selective manipulation of D1R or D2R MSN activity differentially alters addiction-related behaviors (Lobo et al., 2010; Beutler et al., 2011). The potential role of D1Rs in alcohol consumption was previously suggested (Hodge et al., 1997). However, to the best of our knowledge this is the first report suggesting that D1Rs in the DMS play an important role in mechanisms underlying alcohol drinking.

It has recently been shown that DMS neurons respond to multisensory stimulation, including tactile and visual stimulation, and perform multisensory integration (Reig and Silberberg, 2014). In addition, the DMS is critical for action-outcome association that enables goal-directed behaviors (Yin and Knowlton, 2006), which was reported to generate an increase in the synaptic plasticity of D1R but not D2R MSNs of the DMS (Shan et al., 2014). Thus, it is plausible that the alcohol-induced activation of D1R, which in turn increases AMPAR activity in DMS D1R MSNs, could reduce the threshold of alcohol-related sensory stimulation and enhance multisensory integration. As a result, D1R MSNs are hyperexcited (or overstimulated) to initiate "Go" actions during action-outcome association, enhancing the propensity to engage in an alcohol-seeking and alcohol-taking response that may underline the development and maintenance of alcohol consumption. In addition, alcohol-induced abnormal spine maturation from the immature long-thin spines to the mature mushroom spines in DMS D1R MSNs may contribute to the enhancement of consolidation of alcohol-related memories (Mueller et al., 1983; Bruce et al., 1999), which may be contributing to mechanisms underlying pathological alcohol drinking.

In summary, our results suggest that repeated cycles of alcohol drinking and the activation of D1Rs result in sustained functional and structural alterations preferentially in the D1R MSNs of the DMS, which in turn lead to aberrant synaptic and structural plasticity that may contribute to pathological alcohol-related phenotypes.

\section{References}

Arendt T (2001) Disturbance of neuronal plasticity is a critical pathogenetic event in Alzheimer's disease. Int J Dev Neurosci 19:231-245. CrossRef Medline

Bertran-Gonzalez J, Bosch C, Maroteaux M, Matamales M, Hervé D, Valjent E, Girault JA (2008) Opposing patterns of signaling activation in dopamine D1 and D2 receptor-expressing striatal neurons in response to cocaine and haloperidol. J Neurosci 28:5671-5685. CrossRef Medline

Beutler LR, Wanat MJ, Quintana A, Sanz E, Bamford NS, Zweifel LS, Palmiter RD (2011) Balanced NMDA receptor activity in dopamine D1 receptor (D1R)- and D2R-expressing medium spiny neurons is required for amphetamine sensitization. Proc Natl Acad Sci U S A 108:4206-4211. CrossRef Medline

Bock R, Shin JH, Kaplan AR, Dobi A, Markey E, Kramer PF, Gremel CM,
Christensen CH, Adrover MF, Alvarez VA (2013) Strengthening the accumbal indirect pathway promotes resilience to compulsive cocaine use. Nat Neurosci 16:632-638. CrossRef Medline

Bruce KR, Shestowsky JS, Mayerovitch JI, Pihl RO (1999) Motivational effects of alcohol on memory consolidation and heart rate in social drinkers. Alcohol Clin Exp Res 23:693-701. CrossRef Medline

Calabresi P, Gubellini P, Centonze D, Picconi B, Bernardi G, Chergui K, Svenningsson P, Fienberg AA, Greengard P (2000) Dopamine and cAMP-regulated phosphoprotein $32 \mathrm{kDa}$ controls both striatal long-term depression and long-term potentiation, opposing forms of synaptic plasticity. J Neurosci 20:8443-8451. Medline

Calabresi P, Picconi B, Tozzi A, Di Filippo M (2007) Dopamine-mediated regulation of corticostriatal synaptic plasticity. Trends Neurosci 30:211219. CrossRef Medline

Calabresi P, Picconi B, Tozzi A, Ghiglieri V, Di Filippo M (2014) Direct and indirect pathways of basal ganglia: a critical reappraisal. Nat Neurosci 17:1022-1030. CrossRef Medline

Carnicella S, Ron D, Barak S (2014) Intermittent ethanol access schedule in rats as a preclinical model of alcohol abuse. Alcohol 48:243-252. CrossRef Medline

Cazorla M, Shegda M, Ramesh B, Harrison NL, Kellendonk C (2012) Striatal D2 receptors regulate dendritic morphology of medium spiny neurons via Kir2 channels. J Neurosci 32:2398-2409. CrossRef Medline

Corbit LH, Nie H, Janak PH (2014) Habitual responding for alcohol depends upon both AMPA and D2 receptor signaling in the dorsolateral striatum. Front Behav Neurosci 8:301. CrossRef Medline

Cui G, Jun SB, Jin X, Pham MD, Vogel SS, Lovinger DM, Costa RM (2013) Concurrent activation of striatal direct and indirect pathways during action initiation. Nature 494:238-242. CrossRef Medline

Darcq E, Warnault V, Phamluong K, Besserer GM, Liu F, Ron D (2014a) MicroRNA-30a-5p in the prefrontal cortex controls the transition from moderate to excessive alcohol consumption. Mol Psychiatry. Advance online publication. Retrieved October 12, 2014. doi: 10.1038/ mp.2014.120.

Darcq E, Hamida SB, Wu S, Phamluong K, Kharazia V, Xu J, Lombroso P, Ron D (2014b) Inhibition of striatal-enriched tyrosine phosphatase 61 in the dorsomedial striatum is sufficient to increased ethanol consumption. J Neurochem 129:1024-1034. CrossRef Medline

De Gasperi R, Rocher AB, Sosa MA, Wearne SL, Perez GM, Friedrich VL Jr, Hof PR, Elder GA (2008) The IRG mouse: a two-color fluorescent reporter for assessing Cre-mediated recombination and imaging complex cellular relationships in situ. Genesis 46:308-317. CrossRef Medline

Dumitriu D, Rodriguez A, Morrison JH (2011) High-throughput, detailed, cell-specific neuroanatomy of dendritic spines using microinjection and confocal microscopy. Nat Protoc 6:1391-1411. CrossRef Medline

Ferguson SM, Eskenazi D, Ishikawa M, Wanat MJ, Phillips PE, Dong Y, Roth BL, Neumaier JF (2011) Transient neuronal inhibition reveals opposing roles of indirect and direct pathways in sensitization. Nat Neurosci 14: 22-24. CrossRef Medline

Gerfen CR, Surmeier DJ (2011) Modulation of striatal projection systems by dopamine. Annu Rev Neurosci 34:441-466. CrossRef Medline

Gerfen CR, Paletzki R, Heintz N (2013) GENSAT BAC Cre-Recombinase Driver Lines to Study the Functional Organization of Cerebral Cortical and Basal Ganglia Circuits. Neuron 80:1368-1383. CrossRef Medline

Gertler TS, Chan CS, Surmeier DJ (2008) Dichotomous anatomical properties of adult striatal medium spiny neurons. J Neurosci 28:1081410824. CrossRef Medline

Gong S, Zheng C, Doughty ML, Losos K, Didkovsky N, Schambra UB, Nowak NJ, Joyner A, Leblanc G, Hatten ME, Heintz N (2003) A gene expression atlas of the central nervous system based on bacterial artificial chromosomes. Nature 425:917-925. CrossRef Medline

Gong S, Doughty M, Harbaugh CR, Cummins A, Hatten ME, Heintz N, Gerfen CR (2007) Targeting Cre recombinase to specific neuron populations with bacterial artificial chromosome constructs. J Neurosci 27: 9817-9823. CrossRef Medline

Gonzales RA, Job MO, Doyon WM (2004) The role of mesolimbic dopamine in the development and maintenance of ethanol reinforcement. Pharmacol Ther 103:121-146. CrossRef Medline

Hawes SL, Gillani F, Evans RC, Benkert EA, Blackwell KT (2013) Sensitivity to theta-burst timing permits LTP in dorsal striatal adult brain slice. J Neurophysiol 110:2027-2036. CrossRef Medline

Hodge CW, Samson HH, Chappelle AM (1997) Alcohol self-administra- 
tion: further examination of the role of dopamine receptors in the nucleus accumbens. Alcohol Clin Exp Res 21:1083-1091. CrossRef Medline

Honkura N, Matsuzaki M, Noguchi J, Ellis-Davies GC, Kasai H (2008) The subspine organization of actin fibers regulates the structure and plasticity of dendritic spines. Neuron 57:719-729. CrossRef Medline

Huang YH, Lin Y, Mu P, Lee BR, Brown TE, Wayman G, Marie H, Liu W, Yan Z, Sorg BA, Schlüter OM, Zukin RS, Dong Y (2009) In vivo cocaine experience generates silent synapses. Neuron 63:40-47. CrossRef Medline

Kasai H, Fukuda M, Watanabe S, Hayashi-Takagi A, Noguchi J (2010) Structural dynamics of dendritic spines in memory and cognition. Trends Neurosci 33:121-129. CrossRef Medline

Kash TL, Baucum AJ 2nd, Conrad KL, Colbran RJ, Winder DG (2009) Alcohol exposure alters NMDAR function in the bed nucleus of the stria terminalis. Neuropsychopharmacology 34:2420-2429. CrossRef Medline

Kerchner GA, Nicoll RA (2008) Silent synapses and the emergence of a postsynaptic mechanism for LTP. Nat Rev Neurosci 9:813-825. CrossRef Medline

Koob GF, Volkow ND (2010) Neurocircuitry of addiction. Neuropsychopharmacology 35:217-238. CrossRef Medline

Kotecha SA, Oak JN, Jackson MF, Perez Y, Orser BA, Van Tol HH, MacDonald JF (2002) A D2 class dopamine receptor transactivates a receptor tyrosine kinase to inhibit NMDA receptor transmission. Neuron 35: 1111-1122. CrossRef Medline

Lobo MK, Covington HE 3rd, Chaudhury D, Friedman AK, Sun H, DamezWerno D, Dietz DM, Zaman S, Koo JW, Kennedy PJ, Mouzon E, Mogri M, Neve RL, Deisseroth K, Han MH, Nestler EJ (2010) Cell type-specific loss of BDNF signaling mimics optogenetic control of cocaine reward. Science 330:385-390. CrossRef Medline

Mueller CW, Lisman SA, Spear NE (1983) Alcohol enhancement of human memory: tests of consolidation and interference hypotheses. Psychopharmacology 80:226-230. CrossRef Medline

Neve KA, Seamans JK, Trantham-Davidson H (2004) Dopamine receptor signaling. J Recept Signal Transduct Res 24:165-205. CrossRef Medline

Pascoli V, Terrier J, Espallergues J, Valjent E, O’Connor EC, Lüscher C (2014) Contrasting forms of cocaine-evoked plasticity control components of relapse. Nature 509:459-464. CrossRef Medline

Reig R, Silberberg G (2014) Multisensory Integration in the Mouse Striatum. Neuron 83:1200-1212. CrossRef Medline

Ron D, Messing RO (2013) Signaling pathways mediating alcohol effects. Curr Top Behav Neurosci 13:87-126. CrossRef Medline

Russo SJ, Dietz DM, Dumitriu D, Morrison JH, Malenka RC, Nestler EJ (2010) The addicted synapse: mechanisms of synaptic and structural plasticity in nucleus accumbens. Trends Neurosci 33:267-276. CrossRef Medline

Saal D, Dong Y, Bonci A, Malenka RC (2003) Drugs of abuse and stress trigger a common synaptic adaptation in dopamine neurons. Neuron 37:577-582. CrossRef Medline

Schilström B, Yaka R, Argilli E, Suvarna N, Schumann J, Chen BT, Carman M, Singh V, Mailliard WS, Ron D, Bonci A (2006) Cocaine enhances NMDA receptor-mediated currents in ventral tegmental area cells via dopamine D5 receptor-dependent redistribution of NMDA receptors. J Neurosci 26:8549-8558. CrossRef Medline

Shan Q, Ge M, Christie MJ, Balleine BW (2014) The acquisition of goaldirected actions generates opposing plasticity in direct and indirect pathways in dorsomedial striatum. J Neurosci 34:9196-9201. CrossRef Medline

Shen W, Flajolet M, Greengard P, Surmeier DJ (2008) Dichotomous dopa- minergic control of striatal synaptic plasticity. Science 321:848-851. CrossRef Medline

Sholl DA (1953) Dendritic organization in the neurons of the visual and motor cortices of the cat. J Anat 87:387-406. Medline

Spiga S, Talani G, Mulas G, Licheri V, Fois GR, Muggironi G, Masala N, Cannizzaro C, Biggio G, Sanna E, Diana M (2014) Hampered long-term depression and thin spine loss in the nucleus accumbens of ethanoldependent rats. Proc Natl Acad Sci U S A 111:E3745-E3754. CrossRef Medline

Stuber GD, Hopf FW, Hahn J, Cho SL, Guillory A, Bonci A (2008) Voluntary ethanol intake enhances excitatory synaptic strength in the ventral tegmental area. Alcohol Clin Exp Res 32:1714-1720. CrossRef Medline

Sulzer D (2011) How addictive drugs disrupt presynaptic dopamine neurotransmission. Neuron 69:628-649. CrossRef Medline

Tada T, Sheng M (2006) Molecular mechanisms of dendritic spine morphogenesis. Curr Opin Neurobiol 16:95-101. CrossRef Medline

Thornton C, Tang KC, Phamluong K, Luong K, Vagts A, Nikanjam D, Yaka R, Ron D (2004) Spatial and temporal regulation of RACK1 function and $\mathrm{N}$-methyl-D-aspartate receptor activity through WD40 motif-mediated dimerization. J Biol Chem 279:31357-31364. CrossRef Medline

Ungless MA, Whistler JL, Malenka RC, Bonci A (2001) Single cocaine exposure in vivo induces long-term potentiation in dopamine neurons. Nature 411:583-587. CrossRef Medline

Wall NR, De La Parra M, Callaway EM, Kreitzer AC (2013) Differential innervation of direct- and indirect-pathway striatal projection neurons. Neuron 79:347-360. CrossRef Medline

Wang J, Carnicella S, Phamluong K, Jeanblanc J, Ronesi JA, Chaudhri N, Janak PH, Lovinger DM, Ron D (2007) Ethanol induces long-term facilitation of NR2B-NMDA receptor activity in the dorsal striatum: implications for alcohol drinking behavior. J Neurosci 27:3593-3602. CrossRef Medline

Wang J, Lanfranco MF, Gibb SL, Yowell QV, Carnicella S, Ron D (2010a) Long-lasting adaptations of the NR2B-containing NMDA receptors in the dorsomedial striatum play a crucial role in alcohol consumption and relapse. J Neurosci 30:10187-10198. CrossRef Medline

Wang J, Carnicella S, Ahmadiantehrani S, He DY, Barak S, Kharazia V, Ben Hamida S, Zapata A, Shippenberg TS, Ron D (2010b) Nucleus accumbens-derived glial cell line-derived neurotrophic factor is a retrograde enhancer of dopaminergic tone in the mesocorticolimbic system. J Neurosci 30:14502-14512. CrossRef Medline

Wang J, Ben Hamida S, Darcq E, Zhu W, Gibb SL, Lanfranco MF, Carnicella S, Ron D (2012) Ethanol-mediated facilitation of AMPA receptor function in the dorsomedial striatum: implications for alcohol drinking behavior. J Neurosci 32:15124-15132. CrossRef Medline

Wills TA, Klug JR, Silberman Y, Baucum AJ, Weitlauf C, Colbran RJ, Delpire E, Winder DG (2012) GluN2B subunit deletion reveals key role in acute and chronic ethanol sensitivity of glutamate synapses in bed nucleus of the stria terminalis. Proc Natl Acad Sci U S A 109:E278-E287. CrossRef Medline

Wilson CJ (2004) Basal ganglia. In: The synaptic organization of the brain (Shepherd GM, ed), pp 361-414. New York: Oxford UP.

Yaka R, Phamluong K, Ron D (2003a) Scaffolding of Fyn kinase to the NMDA receptor determines brain region sensitivity to ethanol. J Neurosci 23:3623-3632. Medline

Yaka R, He DY, Phamluong K, Ron D (2003b) Pituitary adenylate cyclaseactivating polypeptide (PACAP(1-38)) enhances N-methyl-D-aspartate receptor function and brain-derived neurotrophic factor expression via RACK1. J Biol Chem 278:9630-9638. CrossRef Medline

Yin HH, Knowlton BJ (2006) The role of the basal ganglia in habit formation. Nat Rev Neurosci 7:464-476. CrossRef Medline 